\title{
Kenaikan Berat Badan Bayi Usia 6 Bulan Berdasarkan Pemberian Asi Esklusif dengan Pemberian Susu Formula
}

\author{
Sismala Harningtyas ${ }^{1}$, Rita Sri Kurniawati ${ }^{2}$ \\ sismala.harningtyas@gmail.com, ritasri.1207@gmail.com \\ Sekolah Tinggi IImu Kesehatan Maharani Malang' \\ Universitas Islam Jember²
}

\begin{abstract}
Abstrak
Bayi yang mendapat ASI umumnya tumbuh dengan cepat pada 2-3 bulan pertama kehidupannya, tetapi lebih lambat dibanding bayi yang tidak mendapat ASI eksklusif. Dalam minggu pertama kehidupan sering ditemukan penurunan berat badan sebesar $5 \%$ pada bayi yang mendapat Susu Formula dan $7 \%$ pada bayi yang mendapat ASI. Apabila terjadi masalah dalam pemberian ASI, penurunan berat badan sebesar $7 \%$ dapat terjadi pada 72 jam pertama kehidupan. Penelitian ini merupakan penelitian analitik melalui perbandingan dengan pendekatan Cross Sectional. Penelitian ini bertujuan untuk mengetahui perbandingan berat badan bayi yang mendapatkan ASI dengan yang mendapatkan susu formula pada bayi usia 6 bulan. Populasi dalam penelitian ini berjumlah 112 bayi, besar sampel dalam penelitian ini adalah 53 bayi dengan teknik pengambilan sampel accidental sampling. Hasil dari penelitian ini diketahui bahwa berat badan bayi yang mendapatkan ASI tertinggi 7800 gram dan terendah 6700 gram, sementara berat badan bayi yang mendapatkan Susu Formula tertinggi 9300 gram dan terendah 7000 gram. Berdasarkan uji Wilcoxon Signed Ranks Test, hasil uji ini ini didapatkan bahwa nilai $p=$ $0.000<\mathrm{a}=0.05$, maka ada perbedaan pertumbuhan berat badan bayi yang mendapat ASI eksklusif dan susu formula. Pada penelitian ini terdapat perbedaan kenaikan berat badan bayi usia 6 bulan yang mendapat ASI eksklusif dan susu formula. ASI lebih baik bagi kesehatan bayi karena tidak menyebabkan obesitas, walaupun berat badan bayi yang mendapatkan ASI lebih rendah dibandingkan yang mendapatkan susu formula.
\end{abstract}

Kata kunci: Berat Badan, ASI Eksklusif, Susu Formula

Babies who are breastfed are generally grown rapidly in the first 2-3 months of life, but more slowly than babies who are not exclusively breastfed. In the first week of life are often found weight loss of $5 \%$ in infants who received formula milk and $7 \%$ in infants who are breastfed. If there are problems in breastfeeding, weight loss of $7 \%$ can occur in the first 72 hours of life. This research is analytic through comparison with cross sectional approach. This study aims to determine the ratio of weight to the breast fed infants who received formula milk in infants 6 months of age. The population in this study amounted to 112 infants, the sample size in this study were 53 infants with accidental sampling technique of sampling. The results of this research note that weight breast fed infants highest and lowest 7800 grams 6700 grams, while the weight of infants receiving formula milk highest and lowest 9300 grams 7000 grams. Based on the Wilcoxon Signed Ranks Test, this test result is obtained that the value of $p=0.000<a=0.05$, then there is a difference in the growth of the baby weight that exclusively breastfed and formula. In this study is there is a difference gaining weight infants 6 months of age exclusively breastfed and formula. Breast milk is better for baby's health because it does not cause obesity, although weight infants who received breast milk is lower than the gain formula.

Keywords: Weight Loss, Exclusive breastfeeding, Infant Formula

\section{Pendahuluan}

Berat badan merupakan ukuran antropometrik yang terpenting yang dipakai pada setiap kesempatan memeriksa kesehatan anak pada kelompok umur. Berat badan merupakan hasil peningkatan atau penurunan semua jaringan yang ada dalam tubuh antara lain, Tulang, Otot, Lemak, Cairan tubuh dan lainnya. Berat badan dipakai sebagai indikator yang terbaik pada saat ini untuk mengetahui keadaaan Gizi dan tumbuh kembang anak, sensitive terhadap perubahan sedikit saja, pengukuran obyektif dan dapat diulangi, dapat digunakan timbangan apa saja yang relative murah, mudah dan tidak memerlukan banyak waktu (Soetjiningsih, 2017) .
ASI Eksklusif adalah bayi hanya diberi air susu ibu tanpa tambahan makanan padat dan cair. ASI sebagai makanan alamiah adalah makanan terbaik yang diberikan oleh seseorang ibu kepada bayi yang dilahirkannya pada masa awal kehidupan. (Siswanto, 2018).

Susu Formula adalah susu yang dibuat dari susu sapi atau susu buatan yang diubah komposisinya hingga dapat dipakai sebagai pengganti ASI. Alasan dipakainya susu sapi sebagai bahan dasar disebabkan oleh banyaknya susu yang dapat dihasilkan oleh peternak (Pudjiadi, 2017).

Bayi yang mendapat ASI umumnya tumbuh dengan cepat pada 2-3 bulan pertama kehidupannya, tetapi lebih lambat dibanding bayi yang tidak mendapat ASI eksklusif. Dalam 
minggu pertama kehidupan sering ditemukan penurunan berat badan sebesar $5 \%$ pada bayi yang mendapat Susu Formula dan $7 \%$ pada bayi yang mendapat ASI. Apabila terjadi masalah dalam pemberian ASI, penurunan berat badan sebesar $7 \%$ dapat terjadi pada 72 jam pertama kehidupan.

Berdasarkan hasil Riset Kesehatan Dasar (Riskesdas) tahun 2015, cakupan pemberian ASI Eksklusif bayi 0-5 bulan sebesar 27,2 \%. Pemberian ASI Eksklusif pada bayi usia 5 bulan bahkan hanya 15,3 \% (Depkes RI, 2015). Jumlah bayi menurut data Dinkes Bondowoso tahun 2019 adalah 10523 bayi. Berdasarkan data dari Puskesmas Taman Krocok jumlah bayi yang mendapat ASI Eksklusif pada tahun 2019 adalah sebanyak 6225 bayi (59.16\%), sedangkan bayi yang mendapat Susu Formula adalah sebanyak 1380 bayi $(13,11 \%)$ sisanya adalah MPASI 2918 bayi $(27.73 \%)$.

Diperkirakan salah satu yang menyebabkan adanya masalah nutrisi kurang adalah kurangnya pemberian ASI Eksklusif pada bayi dengan baik, maka tujuan penelitian adalah mengetahui perbedaan kenaikan berat badan pada bayi usia 6 bulan yang mendapatkan ASI Eksklusif dan susu formula.

\section{Metode Penelitian}

Penelitian ini merupakan penelitian analitik dengan menggunakan perbandingan (Comparative study), dengan pendekatan cross sectional. Populasi bayi yang usia 6 bulan yaitu 112 bayi.

Sampel dalam penelitian ini adalah bayi yang berusia 6 bulan yang mendapat ASI Eksklusif dan Susu Formula 53 bayi dengan cara pengambilan sampel yaitu accidental Sampling. Penelitian dilakukan di wilayah kerja Puskesmas Taman Krocok Kecamatan Taman Krocok Kabupaten Bondowoso pada bulan Februari s/d Agustus Tahun 2020. Instrumen pada penelitian ini adalah lembar observasi.

\section{Hasil Dan Pembahasan}

Hasil

Untuk menguji adanya komparasi kenaikan berat badan pada bayi usia 6 bulan yang mendapatkan ASI Eksklusif dan susu formula, maka analisis dilakukan dalam bentuk analisis univariat. Data yang diperoleh diuji dengan menggunakan uji statistik Uji Wilcoxon Rank Tests.

Tabel 1. Perbedaan Kenaikan Berat Badan Bayi yang Mendapat Susu Formula Dengan ASI Karakteristik Responden

\begin{tabular}{ccccc}
\hline No & $\begin{array}{c}\text { Susu } \\
\text { Formula } \\
\text { (gram) }\end{array}$ & $\mathrm{f}$ & ASI (gram) & $\mathrm{f}$ \\
\hline 1 & 6900 & 4 & 6100 & 1 \\
2 & 7000 & 2 & 6300 & 1 \\
3 & 7100 & 2 & 6500 & 3 \\
4 & 7300 & 5 & 6600 & 1 \\
5 & 7500 & 3 & 6700 & 5 \\
6 & 7600 & 8 & 6800 & 6 \\
7 & 7700 & 3 & 6900 & 15 \\
8 & 7800 & 5 & 7000 & 6 \\
9 & 7900 & 6 & 7100 & 5 \\
10 & 8000 & 7 & 7200 & 2 \\
11 & 8200 & 1 & 7300 & 6 \\
12 & 8300 & 1 & 7500 & 1 \\
13 & 8400 & 1 & 7600 & 1 \\
14 & 8600 & 1 & & \\
15 & 9000 & 2 & & \\
16 & 9100 & 1 & & \\
17 & 9300 & 1 & & 53 \\
\hline \multicolumn{5}{c}{ Jumlah } \\
\hline
\end{tabular}

Berdasarkan tabel di atas diketahui bahwa berat badan bayi usia 6 bulan yang mendapatkan ASI tertinggi 7600 gram dan terendah 6100 gram dan yang minum susu formula tertinggi 9300 gram dan terendah 6900 gram.

Tabel 2. Hasil Perbedaan kenaikan berat badan bayi yang mendapatkan susu formula dengan ASI pada usia 6 bulan

\section{Ranks}

\begin{tabular}{|c|c|c|c|c|}
\hline $\begin{array}{l}\text { Berat Badan } \\
\text { Bayi yang }\end{array}$ & $\begin{array}{l}\text { Negative } \\
\text { Ranks }\end{array}$ & $49^{a}$ & 26.76 & 1311.00 \\
\hline $\begin{array}{l}\text { Mendapatka } \\
\text { n ASI Usia 0- }\end{array}$ & $\begin{array}{l}\text { Positive } \\
\text { Ranks }\end{array}$ & $2^{b}$ & 7.50 & 15.00 \\
\hline $\begin{array}{l}6 \text { Bulan - } \\
\text { Berat Badan }\end{array}$ & Ties & $2^{c}$ & & \\
\hline $\begin{array}{l}\text { Bayi yang } \\
\text { Mendapatka }\end{array}$ & Total & & & \\
\hline $\begin{array}{l}\text { n Susu } \\
\text { Formula Usia } \\
\text { 0-6 Bulan }\end{array}$ & & 53 & & \\
\hline \multicolumn{5}{|c|}{$\begin{array}{l}\text { a. Berat Badan Bayi yang Mendapatkan ASI Usia } \\
\text { 0-6 BIn < Berat Badan Bayi yang Mendapatkan } \\
\text { Susu Formula Usia 0-6 Bulan }\end{array}$} \\
\hline \multicolumn{5}{|c|}{$\begin{array}{l}\text { b. Berat Badan Bayi yang Mendapatkan ASI Usia } \\
\text { 0-6 Bulan > Berat Badan Bayi yang Mendapatkan } \\
\text { Susu Formula Usia 0-6 Bulan }\end{array}$} \\
\hline \multicolumn{5}{|c|}{$\begin{array}{l}\text { c. Berat Badan Bayi yang Mendapatkan ASI Usia } \\
\text { 0-6 Bulan = Berat Badan Bayi yang Mendapatkan } \\
\text { Susu Formula Usia 0-6 Bulan }\end{array}$} \\
\hline
\end{tabular}

Berdasarkan tabel diatas diketahui bahwa negatif ranks berat badan bayi yang mendapatkan susu formula dengan yang mendapatkan ASI bayi usia 6 bulan sebanyak 2 bayi. Positif ranks berat badan bayi yang mendapatkan susu formula dengan yang mendapatkan ASI bayi usia 6 bulan sebanyak 49 bayi dan Ties berat badan bayi yang mendapatkan susu formula dengan yang 
mendapatkan ASI bayi usia 6 bulan hanya 2 bayi.

\section{Pembahasan}

Dari Karakteristik responden kenaikan BB bayi yang mendapatkan susu formula lebih banyak dibandingkan dengan bayi dengan ASI Ekskluif. Distribusi Berat Badan Bayi 6 Bulan yang Mendapatkan ASI.

Hasil penelitian menunjukkan bahwa, kenaikan berat badan bayi yang mendapatkan ASI pada usia 6 bulan tertinggi 7600 gram dan terendah 6100 gram. Berat badan bayi ini dipengaruhi oleh asupan gizi yang cukup. Bayi memerlukan asupan gizi yang baik untuk pertumbuhan dan perkembangan. Hasil penelitian ini sesuai dengan teori Depkes RI, (2015), menyatakan bahwa ASI adalah suatu emulasi lemak dalam protein, laktosa dan garam-garam organik yang diseksikan pada hari ke 10 dan seterusnya dengan komposisi yang relatif kontan. ASI merupakan cairan biologis komplek yang mengandung semua nutrien yang dibutuhkan oleh tubuh anak. Berat badan bayi yang mendapat ASI eksklusif, umumnya meningkat dengan cepat tetapi lebih lambat dibanding bayi yang tidak mendapat ASI eksklusif.

Pertumbuhan berat badan bayi yang mendapat ASI lebih ringan dibanding bayi yang mendapat susu formula sampai usia 6 bulan. Hal ini tidak berarti bahwa berat badan yang lebih besar pada bayi yang mendapat susu formula lebih baik dibanding bayi yang mendapat ASI. Berat berlebih pada bayi yang mendapat susu formula justru menandakan terjadi kegemukan. Kegemukan ini dapat berlangsung hingga berjarak dewasa nanti. Adapun bayi yang diberi ASI tidak perlu khawatir akan kegemukan, karena ASI menyesuaikan kebutuhan tubuh bayi itu sendiri (Purwanti, 2015).

Distribusi Berat Badan Bayi 6 Bulan Mendapatkan Susu Formula

Hasil penelitian menggambarkan bahwa kenaikan berat badan bayi yang mendapatkan susu formula pada usia 6 bulan terendah 6900 gram dan tertinggi 9300 gram. Kelebihan berat badan pada bayi yang mendapatkan susu formula diperkirakan karena kelebihan retensi air dan komposisi lemak tubuh yang berbeda dibandingkan ASI. Berat badan bayi sangat erat kaitannya dengan intensitas pemberian susu formula, berdasarkan pengamatan penulis, sebagian besar responden tidak teratur dalam memberikan susu formula, mereka memberika susu formula kapan saja bayi membutuhkan tanpa melihat aturan pakai yang tertera dalam setiap kemasan. Pemberian susu yang tidak teratur bisa menyebabkan resiko obesitas ( Tanuwijaya, 2016).

Hasil penelitian ini sesuai dengan teori Soetjiningsih (2017), bahwa pemberian susu formula memiliki potensi terjadinya obesitas, hipernaytremi dan enterokolitis netrotikans. Obesitas dipengaruhi oleh pemberian susu yang terlalu kental dan jumlah pemberiaan yang terlalu banyak dan menyebabkan gemuk sehingga berat badan bayi bisa bertambah.

Perbedaan Kenaikan Berat Badan bayi yang mendapatkan susu formula dengan ASI

Berdasarkan uji Wilcoxon Signed Ranks Test, hasil uji ini ini didapatkan bahwa nilai $p=0.000$ $<\mathrm{a}=0.05$, maka ada perbedaan pertumbuhan berat badan bayi yang mendapat ASI eksklusif dan susu formula, bayi yang mengonsumsi ASI dapat mengatur asupan kalori sesuai dengan kebutuhannya masing-masing. Kemampuan ini yang diperkirakan menjadi alasan bayi yang mengkonsumsi ASI cenderung kurang memiliki masalah obesitas di kemudian hari.

Suatu penelitian longitudinal terhadap pertumbuhan bayi yang mendapat ASI eksklusif dan bayi yang mendapat susu formula yang dilakukan oleh Horwood LJ (2015), diketahui berat badan terhadap umur dan panjang badan terhadap umur ke-2 kelompok adalah sama pada saat lahir, tetap sama pada umur 112 hari (4 bulan). Perbedaan bermakna terlihat pada kurva berat badan terhadap umur; bayi yang mendapat susu formula lebih tinggi dibanding bayi yang mendapat ASI eksklusif. Demikian pula dengan nilai berat badan terhadap panjang badan; bayi yang mendapat susu formula lebih tinggi dibanding bayi yang mendapat ASI.

Hasil yang mirip juga diperlihatkan oleh penelitian Martin RM (2017) berat badan bayi yang mendapat ASI lebih ringan dibanding bayi yang mendapat susu formula sampai usia 6 bulan. Hal ini bukan berarti bahwa berat lebih pada bayi yang mendapat susu formula lebih baik dibanding bayi yang mendapat ASI. Dr. Katherine Deetwyler dari University of California pada tahun 2010 membandingkan pola pertumbuhan normal antara bayi yang diberi ASI dengan susu formula Bayi yang mendapatkan air susu ibu (ASI) eksklusif dengan bayi yang mendapatkan nutrisi dari susu formula memiliki berat badan yang berbeda. Bayi yang mendapatkan ASI eksklusif cenderung lebih ramping dan sehat dalam jangka waktu yang panjang.

Pertumbuhan bayi yang mendapat ASI lebih jarang mengalami obesitas dibandingkan bayi yang mendapat susu formula. Hal ini disebabkan perbedaan perilaku makan dan perbedaan kandungan zat gizi. Pada bayi yang 
diberikan susu formula, ibu cenderung memberikan susu sampai botolnya kosong. Kadar protein pada susu formula $70 \%$ lebih banyak dibandingkan ASI, membuat bayi terpajang protein kadar tinggi terlalu dini (Roesli, 2017)

\section{Kesimpulan Dan Saran}

Kesimpulan

Berdasarkan hasil penelitian dapat disimpulkan terdapat perbedaan kenaikan berat badan antara yang mendapatkan susu formula dengan yang mendapatkan ASI. Berat badan yang mendapatkan susu formula lebih tinggi dari yang mendapatkan ASI di Wilayah kerja Puskesmas Taman Krocok Kecamatan Taman Krocok Kabupaten Bondowoso Tahun 2020.

Saran

Bidan diharapkan untuk selalu memberikan pemahaman kepada masyarakat secara berkesinambungan melalui penyuluhan tentang perilaku sehat terutama bagi bayi dan diharapkan masyarakat selalu memperhatikan dan mempertimbangkan kesehatan anak dengan selalu menjaga keseimbangan nutrisi dan asupan gizinya. Sehat tidak harus gemuk, tapi kegemukan memiliki resiko sendiri pada bayi.

\section{Daftar Pustaka}

Depkes RI, 2015. Profil Indonesia Sehat. Jakarta, PT Rineka Cipta.

Dettwyler, A Katherine. 2010. The Cultural context Of Breastfeeding in the United States.https://scholar.google.co.id. Diakses 2 April 2020.

Hoorwood, LJ, Darlow. 2015. Breast milk Feeding and cognitive ability.https://scholar.google.co.id.

Diakses 7 Maret 2020.

Martin, RM, Smith, DG. 2017. Assocition Between Breast Feeding and Growth : The Boyd-Orr Cohort Study.https://scholar.google.co.id. Diakses 7 Maret 2020.

Pudjiadi, S. 2017. Ilmu Gizi Klinis pada anak edisi keempat. Jakarta: FK UI.

Purwanti. 2015. Konsep Penerapan ASI Eksklusif. Bandung : Cendekia.

Roesli, Utami. 2017. Mengenal ASI eksklusif. Jakarta: Trubus Agriwidya, Anggota IKAPI

Siswanto, Hadi. 2018. Pendidikan Kesehatan Anak Usia Dini. Yogyakarta : Pustaka Rihama.

Soetjiningsih. 2017. Tumbuh Kembang Anak. Jakarta : EGC

Tanuwijaya, S. 2016. Konsep Umum Tumbuh dan Kembang. Jakarta: EGC 